УДК $1(09)$

DOI: $10.18384 / 2310-7227-2020-4-64-71$

\title{
METHODOLOGICAL FEATURES OF RUSSIAN RELIGIOUS PHILOSOPHY
}

\author{
Michio Mikoshiba ${ }^{1}$, Ya. Bondareva ${ }^{2}$ \\ ${ }^{1}$ Chiba University \\ 1-33 Yayoi-cho, Inage-ku, Chiba-shi 263-8522, Japan \\ ${ }^{2}$ Moscow Region State University \\ 24 Very Voloshinoy ul.. Moscow region, Mytischi 141014, Russian Federation
}

\begin{abstract}
.
Aim. To reveal the methodological features of Russian religious philosophy, to analyze such basic methods for Russian philosophical culture as phenomenological and existential.

Methodology. The research was carried out on the basis of the principles of historical and philosophical research (historicism, ideological and theoretical continuity, concreteness), and systemic approach.

Results. It is the phenomenological and existential methods of Russian religious philosophy that considering in profound and different ways the issues of the subject and object of cognition; the subject of philosophical knowledge, and the issue of its truth in general, solve the common problem - cognition of «true being», the transcendental divine principle through which the meaning of personal existence can be revealed. Synthesizing these methods with mystical experience, Russian thinkers moved along the path of creating "integral knowledge" within the Christian paradigm.

Research implications. The study of the deep methodological phenomena of Russian religious thought presupposes further development of religious and philosophical knowledge, and the conclusions drawn from the analysis of the synthesis of rationalistic, phenomenological and mystical methods of cognition may help in understanding the ways of development of modern science.
\end{abstract}

Keywords: holistic knowledge, total unity, knowledge, phenomenological method, existential method, truth, intuition

\section{МЕТОДОЛОГИЧЕСКИЕ ОСОБЕННОСТИ РУССКОЙ РЕЛИГИОЗНОЙ ФИЛОСОФИИ}

\author{
Митио Микосиба ${ }^{1}$, Бондарева Я. В. ${ }^{2}$ \\ ${ }^{1}$ Университет г. Тиба (Япония) \\ 263-8522, преср. Тиба, г. Тиба, р-н Инагэ, ул. Яёй, Япония \\ ${ }^{1}$ Московский государственный областной университет \\ 141014, Московская область, г.Мытищи, ул. Веры Волошиной, д. 24, Российская Федерация
}

\section{Аннотация.}

Цель. Выявить методологические особенности русской религиозной фрилососии, проанализировать фееноменологический и экзистенциальный методы как базовые для русской философской культуры.

Процедура и методы. Исследование осуществлялось на основе принципов историкофиллософского анализа (историзма, идейно-теоретической преемственности, конкретности), а также с применением системного подхода.

Результаты. По итогам исследования сделан вывод о том, что именно феноменологический и экзистенциальный методы русской религиозной фрилософии, в деталях по-разному решая вопросы субъекта и объекта познания, предмета философского знания, а также вопрос о его истинности, в целом решают одну и ту же задачу - познание «живого подлинного бытия», Божественного начала, запредельного миру, и через него раскрывают смысл личного (c) CC BY Michio Mikoshiba, Ya. Bondareva, 2020. 
существования. Синтезируя эти методы с мистическим опытом, русские мыслители продвигались по пути создания «цельного знания» в рамках христианской парадигмы.

Теоретическая и/или практическая значимость. Изучение глубинных, методологических явлений русской религиозной мысли предполагает дальнейшее развитие религиознофилософского знания, а выводы, сделанные в результате анализа синтеза рационалистического, феноменологического и мистического методов познания, возможно, помогут в осмыслении путей развития современной науки.

Ключевые слова: цельное знание, всеединство, познание, феноменологический метод, экзистенциальный метод, истина, интуиция.

\section{Introduction}

Russian religious philosophy, setting itself the task of transforming philosophy into contemplation, moving the mind into the sphere of apophatism and symbolic realism, inevitably solved the question of the reality of mystical experience, the possibility of conscious communication with God, the ultimate calling of man, the possibility of his deification. Trying to reveal Orthodoxy through philosophical synthesis, Russian thought used phenomenological, existential and mystical methods, which were not only closely related, but also in a state of interdependence [1-4].

\section{Phenomenology and intuitionism}

The most important step towards the correlation of experimental knowledge and philosophical speculation is the phenomenological method, synthesizing its Husserlian interpretation and intuitionism, which was developed in detail in the philosophy of N. Lossky and S. Frank. Somewhat earlier, an element of intuitionism entered the epistemological views of $\mathrm{V}$. Solovyov and was justified in the spirit of Schellingism as «intellectual intuition», which is «a real primary form of integral knowledge» $[18 ; 208]$. He saw the function of intuitive cognition in giving the form of a universal integral truth to the material that is accumulated by the subject through experience. Proceeding from the principle of total unity, substantiating the concept of «free theosophy» as the unity of mysticism, rationalism and empiricism, the philosopher saw in intuition a method in which «one in all» and «all in one» is given [18, c. 233]. Treating intellectual intuition as contemplation ideas, V. Solovyov distinguished it from both rational constructions and mystical experience, which was further developed in the philosophy of N. Lossky, however, unlike the intuitive philosophers, V.Solovyov was more cautious about the degree of entry into our consciousness of the cognized object in intellectual intuition, favouring more the theory of reflection, which is clearly at odds with the phenomenological method. Speaking about the possibilities of cognizing beings through phenomena, the philosopher argued, "It is quite obvious that our knowledge cannot contain this being in its very true being or materially, just as the image in the mirror does not contain the materially depicted object, for then they would be identical and there would be no image" [18, c. 211]. At the same time, V. Solovyov was convinced that the allunity as the beginning of existence could not be unconditionally external for the cognizing subject, but should be in internal connection with them, which can be cognizable "by virtue of the same connection, the subject can be internally connected with everything that exists, as being contained in the all-unity, and really cognize it all" [17, c. 685]. It was the last judgment of V. Solovyov that became organic for the intuitionism of N. Lossky and S. Frank and revealed the mechanism of this internal connection.

The concept of "intuition", semantically ascending to the Latin intueri (to look intently), is understood by N. Lossky as existing independently of the act of cognition, which is equally relevant to sensory, intellectual and mystical intuition. This means that philosophical intuitionism eliminates intermediaries in the process of cognition (copies, symbols, etc.), based on the principle of universal im- 
manence, where "everything is immanent to everything” [14, c. 137].

Here one could reproach N. Lossky for excessive immanentism, caused by the need to substantiate all-unity, but the philosopher claims that intuition is the sum of usual methods of cognition applied by the cognizing subject (consciousness) of trans-subjective being. Therefore, according to N. Lossky, intuitionism argues unconditional recognition of the transcendental reality, the divine principle in being. A similar position is characteristic of the N. Lossky's like-minded thinker S. Frank: for the cognized (experienced) to become some objective content opposing the stream of consciousness, it is necessary to refer it to something outside the stream of experiences itself, i.e. to the area of transcendental being or "timeless unity" (analogous to Lossky's "trans-subjective being").

The concept of intentionality, traditional for phenomenology, which is interpreted as the main condition of intuition, and as an objectifying function of consciousness, and as a cognitive methodology, helps philosophersintuitionists remain within the framework of transcendentalism. Intentionality can be understood as a state of orientation of consciousness, its ability to differentiate into a subject and an object, into "I" and "opposed to me". It is the entry into the being of the cognized through acts of attention, contemplation, striving, desire, etc., which is interpreted by S. Frank as penetration into the "unknown beyond", leading, in turn, to direct awareness of the unity of the transcendent and immanent, the all-unity. "Whatever our consciousness is directed at", writes S. Frank, "it is always directed not at immanent experience as such, but at it as a side or part of absolute being (total unity)" [19, c. 23]. Intuition The philosopher transfers all-unity to the plane of the relationship between the part and the whole, where the part is a particular, peculiar content of knowledge, and the whole is the integrity of everything else: "If each particular content were something closed in itself and therefore open and known for us, outside the relationship to something else, then we could only have or not have it, but knowledge ... would be impossible because it would involve a contradiction" [19, c. 238]. Therefore, the general idea of being must have a consistent and comprehensive character, represent basis for integral knowledge and be solved within the framework of a single system of ideas about the world. As for the factors of being transcended from it (as, for example, the divine principle), they cannot be thought without immanence in their consciousness, without them being present in thinking. Intuitive cognition, therefore, is based on the recognition that the very intelligibility of transcendence testifies to its involvement in world being, and super rationality, trans-subjectivity, meta-logicality of transcendental principles speak not only of the single being of the phenomenal world, but of the all-unity of being, containing various levels reality [5].

The obvious ontologism of the epistemological constructions of intuitionism solves the problem of the optimal combination of transcendentalism and immanentism. The analysis of the relationship between two aspects of consciousness - the subject and the object of cognition - carried out in phenomenology with the help of a special method phenomenological reduction, seeks to reveal that area of being ("pure consciousness") that remains unaffected by reflections carried out within the framework of our natural attitudes. Consciousness is viewed as a unique area of being, which can be revealed using the phenomenological method without any serious distortions. This "knowledge-being" is correlated with the tradition of ontological epistemology in Russian philosophy, within which the existential foundations of consciousness are revealed [8; 9].

For such identification, N. Lossky introduces the concept of supratemporal and supraspatial "epistemological coordination", which he interprets as a connection of substantial figures with each other, thanks to which everything that one figure experiences exists not only for him, but also for all other figures. This makes possible consubstantial substantial figures: "As a result of consubstantiality and epistemological coordination, every element of the external world exists not only 
in itself and for itself, but also for another ... which is an individual. This primary transcending of the individual beyond himself, connecting him with the whole world, is not consciousness, but something more primary and more deeply ontological than consciousness; it is the primary existence of all the elements of the world for me; it is a condition for the development of consciousness and can be called preconsciousness" [13; c. 534]. Thus, preconsciousness is the existential foundation of consciousness, which brings N. Lossky's intuitionism closer to S. Franck who explains the possibility for the subject to directly contemplate not only the content of their own consciousness, but also the transcendental being by the priority of all-embracing being over consciousness. All-encompassing being, according to Frank, rises above the opposition of the subject and the object and embraces it in itself; it is Absolute Being or All-Unity.

Epistemological coordination as a principle of the connection of the subject (substantial figure) with the objects of the external world is at the same time the moment of difference between intuitive cognition and phenomenological one, which focuses its attention on the relations of subordination in cognition, the dependence of one being on another, as in the case of cause-and-effect relationships. By the concept of "coordination" N. Lossky emphasizes the equality of the subject and the object of cognition, which exists before the epistemological experience, but manifests itself in it and explains the very possibility of this experience. Therefore, the philosopher designates this coordination as epistemological, "since it is a condition for the possibility of truth about an object" [14, c. 147]. This judgment makes it necessary to analyze the problem of the truth of intuitive cognition in Russian philosophy, but firstly it is necessary to consider its main types (sensory, intellectual, mystical intuition) according to the degree of their correlation with the phenomenological method, as well as their characteristic features.

Sensual intuition in the interpretation of N. Lossky is based on empirical perception, which is a part of the mental and physiological life of the subject. As the lowest level of cogni- tion, sensory intuition gives the most "polluted" knowledge, immersed in the world of "second nature", which contributes to the atrophy of the ability to see the living dynamic essence of being. Nevertheless, this type of cognition acquires importance and necessity, since it is through it that the subject receives most of the knowledge about the world around him. Sensual intuition is the grasping of the essence of a thing through an intentional selection of perception, when consciousness chooses from a multitude of empirical facts what its attention is directed to. Lossky calls this act "sampling of individual components" of sensory perception, as a result of which the essential basis of a thing in its phenomenal manifestation is represented in consciousness.

Sensual intuition like other levels of intuition, is based on the principle of epistemological coordination and intuition of total-unity, as a result of which it is possible to trust external (trans-subjective) being. Otherwise, consciousness is threatened by the trap of subjectivity and solipsism, in order to avoid which, it was necessary for intuitive philosophers to accept a number of fundamental assumptions, assumptions that determine a specific method of cognition. Such assumptions are the principle of epistemological coordination, the principle of transcendence, which is also present in the relations of substantial figures, the principle of intentionality of consciousness, thanks to which the process of sampling of perception is possible. All these assumptions turn out to be necessary for intuitionism, since, without accepting something as a basis, it is impossible to carry out any reasoning [10].

In contrast to sensory intuition as a stage of empirical knowledge, intellectual intuition in the interpretation of N. Lossky is speculation, thinking, the ability to perceive the ideal unity of the world and its individual aspects. Intellectual intuition, as a merit of reason, turns out to be closely related to sensory intuition, since perception as the initial moment of judgment is always permeated with a large number of ideal aspects of a synthetic nature. The substantial basis of a thing, the belonging of qualities to it, their unity cannot be the sub- 
ject of sensory perception. The sense organs record only certain empirical facts, but their synthesis, the idea of eidos, which underlies the unity of objects, is the comprehension of the ideal aspect of being, accessible only to intellectual intuition, thinking, speculation, understanding [14, c. 199]. Intellectual intuition encompasses all relations belonging to the field of the ideal: unity, plurality, similarity, difference, equality, causality, interaction, etc. These relations are positioned by N. Lossky as trans-subjective, not a subjective product of consciousness, therefore, thinking does not create these relations, but finds them in the object, reveals them through intellectual contemplation. These relations form the structure of the cognized object, its systemic nature, without which the very knowledge about it is impossible.

Epistemological coordination as a principle of the connection of the subject (substantial figure) with the objects of the external world is at the same time the moment of difference between intuitive cognition and phenomenological one, which focuses its attention on the relations of subordination in cognition, the dependence of one being on another, as in the case of cause-and-effect relationships. By the concept of "coordination" N. Lossky emphasizes the equality of the subject and the object of cognition, which exists before the epistemological experience, but manifests itself in it and explains the very possibility of this experience. Therefore, the philosopher designates this coordination as epistemological since it is a condition for the possibility of truth about an object. This judgment makes it necessary to analyze the problem of the truth of intuitive cognition in Russian philosophy, but first it is necessary to consider its main types (sensory, intellectual, mystical intuition) according to the degree of their correlation with the phenomenological method, as well as their characteristic features $[15$, c. 16$]$.

\section{Existentialism and mysticism}

However, if the phenomenological method is aimed at cognizing an object, often, however, combining knowledge "object" with knowledge without an object and aiming at cognition not only of objective being, but also of the being of the human personality itself (as was the case in Russian intuitionism), then the existential method, although it grows out of the depths of phenomenology, it changes its attitude to the "world of objects», turning life to itself, making personal reflection on the meaning of personal existence the subject of philosophical knowledge. In Russian philosophy the existential method found its most striking manifestation in N. Berdyaev, who completely broke with the idea of the object, shifting the center of gravity into the sphere of non-objectified cognition - a person's direct cognition of his essence, his initial, pre-existent freedom.

"Objective knowledge", writes N. Berdyaev, "is itself defective and sinful and is the source of the world's fallen... The objectified world is a godless and inhuman world. The objectification of God is His transformation into a godless and inhuman thing" [7, c. 83]. According to the philosopher, objectified knowledge is the lowest stage, since it cognizes only the general and does not give the cognition of "being in itself". "Nonobjective" knowledge, on the contrary, is pure freedom, active comprehension, the creative reaction of enlightened freedom to being, a change in being.

Free use of the concepts "objectivity" and "objectivity", which often leads to their confusion, introduces, according to the researchers of philosophy N. Berdyaev, some confusion in the question of the truth of knowledge obtained by the existential method. Meanwhile "objectivity" as a form of knowledge, expressed in the category of an object, does not correlate in any way with "objectivity" (truth) as the correct expression of the cognized. "It is necessary to start with a decisive break between true and objectivity", writes N. Berdyaev, however, it should be noted that knowledge can be correctly expressed, and therefore true and, therefore, objective, however, without spilling into the shape of an object. And, conversely, knowledge can be "objective", but incorrectly expressed and untrue. This is an essential 
difference, which overlooks both N. Berdyaev and all related philosophical trends. Indeed, when N. Berdyaev speaks of existence as a direct expression of initial freedom, he is quite convinced that that in his statements this freedom is adequately expressed and in this sense is objective, i.e. true. For him, the manifestation of freedom seems to be true, objective, since it reveals true being as an objective truth. At the same time, according to N. Berdyaev, the identification of freedom does not take place in an objective form, i.e. from the outside, like the study of objects of material nature, but in order to observe the objective fact of freedom, one must live and think without resorting to objectification.

At the same time, the complete destruction of the "objectivity" of knowledge, according to critics of philosophy N. Berdyaev, can lead to the loss of the subject of philosophical knowledge as such. And, nevertheless, the philosophical tradition of defining cognizable being as an object or object of cognition is alien to N. Berdyaev, since in this case it is necessary to recognize the existence of a self-sufficient being, independent of the «I». The existential method presupposes the very possibility of cognition insofar as the cognized is immanent to the cognizing "I", and is not rejected from it as some kind of remote objectivity: "The spirit in me", says N. A. Berdyaev, "is an integral being of another being, resting in itself and apart from me, no. To assume it is arbitrary and illusion" [6, c. 34].

The existential method meets the high requirements that $\mathrm{N}$. Berdyaev makes to each act of cognition, namely, the search for ways of interaction between two natures - human and divine, as well as the solution of the problem of God-manhood. These requirements are presented by N. Berdyaev to philosophy as an expression of religious experience, and this makes him look for the possibility of synthesizing existential and experiential-mystical knowledge. Religious faith becomes the source of his existential philosophy, calling into question the truth of not only rational knowledge, but knowledge in general. According to L. Shestov $[11 ; 12]$, existential knowledge is knowledge "from the depths", it "waits for an answer not from our understanding, not from vision - but from God" [20, c. 423].

\section{Conclusion}

Thus, both phenomenological and existential methods, solving in detail in different ways the issues of the subject and object of cognition, the subject of philosophical knowledge, as well as the question of its truth, in general, solve the same problem - cognition of "true being", divine principle, beyond the world, and through it revealing the meaning of personal existence. Synthesizing these methods with experimental and mystical knowledge, domestic thinkers moved along the path of creating "integral knowledge" on the methodological basis of Christianity [21].

Статья поступиила вредакиию 26.11.2020.

\section{ЛИТЕРАТУРА}

1. Алёхина Е. В. Актуальные проблемы философии: природа человека и смысл его существования. Человек в системе философского знания. М.: ИИУ МГОУ, 2018. 436 с.

2. Алёхина Е. В. Концепция смысла жизни в русской религиозной философии конца XIX - первой половины ХХ века М.: ИИУ МГОУ, 2011. 280 с.

3. Алёхина Е. В. Человек-в-мире: русские религиозные философы о смысле мирового бытия // Философия и культура. 2011. № 2 (38). С. 3-41.

4. Алёхина Е. В. Космологический аспект смысла жизни в русской религиозной философии (конец XIX - первая половина XX века) // NB: Философские исследования. 2013. № 6. С. 545-589.

5. Архангельская Н. О. Эволюция взглядов А. Д. Кантемира и «Письма о природе и человеке» // Вестник Тверского государственного университета. Серия: Философия. 2020. № 2 (52). С. 124-137.

6. Бердяев Н. А. О назначении человека. Париж, YMCA PRESS, 1931. 150 с.

7. Бердяев Н. А. Я и мир объектов. Париж, YMCA PRESS 1947, 191 с.

8. Буренков С. В. Феномен неотчуждённого труда: автореф. дис. ... канд. филос. наук. М., 2017. 22 с. 
9. Буренков С. В. Поиск области позитивной эвристики феномена идеологии // Вестник Московского государственного областного университета. Серия: Философские науки. 2012. № 3. С. 28-34.

10. Колесниченко Ю. В. Личность в русской философии 1920-1930-х годов: биография идеи. М.: Энциклопедист-Максимум, 2018. 416 с.

11. Курабцев В. Л. Альтернатива Льва Шестова // Общественные науки и современность. 1991. № 2. C. $175-181$.

12. Курабцев В. Л. «Мудрейшие из людей» (Лев Шестов и античная философия) // Вопросы философии. 2002. № 11. С. 184-195.

13. Лосский Н. О. Избранное. М.: Правда, 1991. 340 с.

14. Лосский Н. О. Чувственная, интеллектуальная и мистическая интуиция. М.: Республика, 1995. $400 \mathrm{c.}$

15. Мирошкин М. С. Идея бессмертия в философии хозяйства С. Н. Булгакова // Вестник Тверского государственного университета. Серия: Философия. 2017. № 2. С. 153-158.

16. Мирошкин М. С. Философия хозяйства: «духовное» vs «животное» // Вестник Тверского государственного университета. Серия: Философия. 2020. № 2 (52). С. 161-170.

17. Соловьёв В. С. Критика отвлечённых начал // Соловьёв В. С. Сочинения в 2 т. Т. 1. М., 1990. С. 581-756.

18. Соловьёв В. С. Философские начала цельного знания // Соловьёв В. С. Сочинения в 2 т. Т. 2. М., 1990. С. 757-831.

19. Франк С. Л. Предмет знания. Душа человека. СПб.: Наука, 1995. 656 с.

20. Шестов Л. Николай Бердяев. Гнозис и экзистенциальная философия // Русский путь. Т. 1. Антология. Кн. 1. СПб., 1994. С. 156-165.

21. Philosophical and pedagogical aspects of career guidance policy for learners and students / E. V. Alekhina, A. L. Zolkin, R. N. Parkhomenko, A. I. Pirogov, A. L. Safonov, V. S. Zapalatskaya, O. G. Krasnoshlikova // Journal of Environmental Treatment Techniques. 2020. Vol. 8. № 1. C. 175-181.

\section{REFERENCES}

1. Alekhina E. V. Aktual'nye problemy filosofii: priroda cheloveka i smysl ego sushchestvovaniya. Chelovek v sisteme filosofskogo znaniya [Actual problems of philosophy: the nature of man and the meaning of his existence. Man in the system of philosophical knowledge]. MRSU Ed. off. Publ., 2018. 436 p.

2. Alekhina E. V. Kontseptsiya smysla zhizni v russkoi religioznoi filosofii kontsa XIX - pervoi poloviny XX veka [The concept of the meaning of life in Russian religious philosophy of the late XIX - first half of the XX century]. Moscow, MRSU Ed. off. Publ., 2011. 280 p.

3. Alekhina E. V. [Man-in-the-world: Russian religious philosophers on the meaning of world existence]. In: Filosofiya i kul'tura [Philosophy and culture], 2011, no. 2 (38), pp. 3-41.

4. Alekhina E. V. [The cosmological aspect of the meaning of life in Russian religious philosophy (late XIX first half of the XX century)]. In: NB: Filosofskie issledovaniya [NB: Philosophical Studies], 2013, no. 6, pp. 545-589.

5. Arkhangel'skaya N. O. [A. D. Kantemir's evolution of views and "Letters about nature and man"]. In: Vestnik Tverskogo gosudarstvennogo universiteta. Seriya: Filosofiya [Bulletin of Tver' State University. Series: Philosophy], 2020, no. 2 (52), pp. 124-137.

6. Berdyaev N. A. O naznachenii cheloveka [The destiny of the man]. Paris, YMCA PRESS Publ., 1931.150 p.

7. Berdyaev N. A. YA i mir ob"ektov [Me and the world of objects]. Paris, YMCA PRESS Publ., 1947. 191 p.

8. Burenkov S. V. Fenomen neotchuzhdeennogo truda: avtoref. diss. ... kand. filos. nauk [The phenomenon of non-alienated labor: abstract of PhD thesis in Phylosophy sciences]. Moscow, 2017. 22 p.

9. Burenkov S. V. [Search for the area of positive heuristics of the phenomenon of ideology]. In: Vestnik Moskovskogo gosudarstvennogo oblastnogo universiteta. Seriya: Filosofskie nauki [Bulletin of the Moscow State Regional University. Series: Philosophy], 2012, no. 3, pp. 28.

10. Kolesnichenko Yu. V. Lichnost' v russkoi filosofii 1920-1930-kh godov: biografiya idei [Personality in Russian Philosophy of the 1920s - 1930s: Biography of an Idea]. Moscow, Entsiklopedist-Maksimum Publ., 2018. 416 p.

11. Kurabtsev V. L. [Alternative Lev Shestov]. In: Obshchestvennye nauki i sovremennost' [Social sciences and modernity], 1991, no. 2, pp. 175-181.

12. Kurabtsev V. L. ["The wisest of people" (Lev Shestov and ancient philosophy)]. In: Voprosy filosofii 
[Philosophy questions], 2002, no. 11, pp. 184-195.

13. Losskiy N. O. Izbrannoe [Selected works]. Moscow, Pravda Publ., 1991. 340 p.

14. Losskiy N. O. Chuvstvennaya, intellektual'naya i misticheskaya intuitsiya [Sensual, intellectual and mystical intuition]. Moscow, Respublika Publ., 1995. 400 p.

15. Miroshkin M. S. [The idea of immortality in the philosophy of management S. N. Bulgakov]. In: Vestnik Tverskogo gosudarstvennogo universiteta. Seriya: Filosofiya [Bulletin of Tver' State University. Series: Philosophy], 2017, no. 2, pp. 153-158.

16. Miroshkin M. S. [Economy philosophy: "spiritual" vs "animal”]. In: Vestnik Tverskogo gosudarstvennogo universiteta. Seriya: Filosofiya [Bulletin of Tver' State University. Series: Philosophy], 2020, no. 2 (52), pp. 161-170.

17. Solov'eev V. S. [Critics of Abstract Beginnings]. In: Solov'eev V. S. Sochineniya [Criticism of abstract principles. Works. Vol. 1]. Moscow, 1990, pp. 581-831.

18. Solov'eev V. S. [Philosophical principles of integral knowledge]. In: Solov'eev V. S. Sochineniya [Criticism of abstract principles. Works. Vol. 2]. Moscow, 1990, pp. 757-831.

19. Frank S. L. Predmet znaniya. Dusha cheloveka [The subject of knowledge. The soul of the man]. St. Petersburg, Nauka Publ., 1995. 656 p.

20. Shestov L. [Nikolay Berdyaev. Gnosis and Existential Philosophy]. In: Antologiya. Kn. 1 [Russian way. Anthology. B. 1]. St Petersburg, 1994, pp. 156-165.

21. Alekhina E. V., Zolkin A. L., Parkhomenko R. N. et al. [Philosophical and pedagogical aspects of career guidance policy for learners and students]. In: Journal of Environmental Treatment Techniques, 2020, vol. 8 , no. 1, pp. 175-181.

\section{INFORMATION ABOUT THE AUTHORS}

Michio Mikoshiba -Dr. Sci. (Philosophy), Prof., Emeritus of Chiba University, Japan

Yana V. Bondareva - Dr. Sci. (Philosophy), Prof., Head of the Department of Philosophy, Moscow Region State University;

e-mail: bondareva.iana@yandex.ru

\section{ИНФОРМАЦИЯ ОБ АВТОРАХ}

Митио Микосиба - доктор философских наук, почетный профессор Университета Чиба, Япония;

Бондарева Яна Васильевна - доктор философских наук, профессор, заведующий кафедрой философии Московского государственного областного университета;

e-mail: bondareva.iana@yandex.ru

\section{FOR CITATION}

Michio Mikoshiba, Ya. V. Bondareva. Metodological Features of Russian Religious Philosophy. In: Bulletin of the Moscow State Regional University. Series: Philosophical Sciences, 2020, no. 4, pp. 64-71.

DOI: $10.18384 / 2310-7227-2020-4-64-71$

\section{ПРАВИЛЬНАЯ ССЫЛКА НА СТАТЬЮ}

Митио Микосиба, Бондарева Я. В. Методологические особенности русской религиозной философии // Вестник Московского государственного областного университета. Серия: Философские науки. 2020. № 4. C. $64-71$.

DOI: $10.18384 / 2310-7227-2020-4-64-71$ 